\title{
ISPARTA EVLENME ADETLERi ${ }^{*}$
}

\author{
WEDDING CUSTOMS IN ISPARTA
}

\author{
Deniz ÇELiKER ${ }^{* *}$, Mustafa GENÇ**
}

\section{Öz}

Kültürümüzde evlenme, sadece kız ve erkek için değil aynı zamanda iki tarafın aileleri içinde yeni akrabalık bağlarının kurulduğu kutlu bir süreçtir. Genel olarak her yörede kız isteme, söz, nişan ve düğün törenlerinin sıralaması aynıdır. Ancak, törenlerin gün sayısı, hangi günler yapılacağı, bu günlerde yapılan işler ve günlere verilen isimler, bu süreçte yerine getirilen adetler, yapılan ikramlar, çeyiz ve ağırlık olarak verilen eşyalar, giyim-kuşam, sözlü kültür unsurları, törenlerin yapıldığı toplumun kültürüne göre şekillenerek bugüne gelmiştir. Geleneksel evlenme ritüelleri hangi yörede olursa olsun meşakkatli ve bir o kadar biricik kutlamalardır. Birçok yörede modern zamanın getirdiği teknolojik kolaylıklar, moda vb. unsurlar ile geleneksel evlenme ritüelleri değişime uğramış hatta bazı yerlerde unutulmaya yüz tutmuştur. Ancak Isparta; ilçeleri, köy ve kasabaları ile evlenme adetlerinin geçmişten bugüne devam ettirmeye çalışan bir ilimizdir. Bu çalışmada Isparta ili evlenme adetleri; kız isteme, söz, nişan ve düğün süreçleri ilçelerdeki farklı uygulamalarıyla tanıtılmaya çalışılmıştır.

Anahtar Kelimeler: Isparta, Düğün, Kültürel Bellek, Geleneksel Giyim, Somut Olmayan Kültürel Miras.

\begin{abstract}
Marriage in ou rculture is a happy process in which new kinshipties are established not only for boys and girls but also for the families of bothsides. In general, the order of requesting, promising, engagement and wedding ceremonies is the same in every region. However, the number of days of ceremonies, which days to be held, the work done on these days and the names given to the days, the customs performed in this process, the treats, dowry and weight given goods, clothing-dressing, oral culture elements, ceremonies are shaped according to the culture of the societylt has come. Traditional marriage rituals are hard and unique celebrations, no matter in which region. Technological conveniences brought by modern time in many regions, fashion and so on. Elements and traditional marriage rituals have been changed and even forgotten in some places. However, Isparta; districts, villages and towns from past to present is a province that tries to continue marriage. In this study; girl

\footnotetext{
**Bu araştırma, 18-19-20 Nisan 2019 tarihlerinde Isparta, Süleyman Demirel Üniversitesi'nde gerçekleşen 2. Somut Olmayan Kültürel Miras Çalıştayı'nda sözlü bildiri olarak sunulmuştur. ${ }^{* * *}$ Dr. Öğr. Üyesi, Süleyman Demirel Üniversitesi, Güzel Sanatlar Fakültesi, Tekstil ve Moda Tasarımı Bölümü, denizceliker@sdu.edu.tr, https://orcid.org/0000-0002-1869-0885.

******Doç. Dr., Süleyman Demirel Üniversitesi, Güzel Sanatlar Fakültesi, Geleneksel Türk Sanatları Bölümü, mustafagenc@sdu.edu.tr, https://orcid.org/0000-0001-8702-538X.

**** Isparta Evlenme Adetleri" başlıklı bu çalışma 2017 yılında Süleyman Demirel Üniversitesi Rektörlüğü ve Süleyman Demirel Üniversitesi Bilimsel Araştırma Projeleri Koordinasyon Birimi desteği ile başlatılan "Isparta Somut Olmayan Kültürel Mirasın Tespiti" isimli proje verilerinden ve görsellerinden yararlanılarak hazırlanmıştır.
} 
request, word, engagement and wedding processes are tried to be introduced with different applications in the districts.

Keywords: Isparta, Weddings, Cultural Memory, Traditional Clothing, Intangible Cultural Heritage.

\section{Giriş}

Bireylerin tutum ve davranışları toplumda kabul görme isteği ile ilişkilidir. Bu nedenle ait olduğu toplumun yazılı olmayan kurallarına uyarak, toplumun kültür değerleri ile kendilerini var ederler. Toplum içinde kabul görme, yeni bir statü kazanma yöntemlerinden biri de aile kurmaktır. Aile kurma isteği ve süreci görece bilinenin aksine ergenlik çağına gelmiş bireylerin tanışması/tanıştırılması ya da görücülük süreci ile başlamaz; bir çocuğun doğumu ile başlar. Ebeveynleri tarafından doğan çocuk kız ise alınan oyuncak ve oynanan oyunlarla iyi bir eş, anne olma becerisi; erkek ise er olma becerisi kazandırılmaya çalışılır. Bir örnek olarak bu oyunlar aslında anne ve babanın ait olduğu toplumun kültürel değerlerini aktarma şekli ve çocuğuna yetişkinlik rolünü öğretmesi ile ileride toplum tarafından kabul edilmesi için verilen eğitimdir. Yine bir başka örnekle insan hayatının geçiş evrelerinin bir alt evresi olan sünnet, çocuğun gelecekte yapacağı düğün için bir hazırlıktır. Sünnet olacak çocuk için dikilen yorgan, sünnet töreninden sonra kullanılmayarak yüklüğe kaldırılır. Sünnet çocuğu büyüyüp damat olduğunda bu yorgan çeyiz olarak kendisine verilecektir. Bu nedenle sünnet yorganı iki kişiliktir ve (evliliği iyi olan, eşi sağ olan kadınların getirdiği iğnelerle dikilmesi, yorgan içine nazardan korumak için çörek otu atılması, dua ile dikime başlanması vb.) bazı ritüellere uyularak dikilir. Erkekliğe ilk adımı atan erkek çocuğuna aile ve akraba/komşu kadınlar tarafından gelecekte bir aile kurması gerekliliği; aileye ise yeni kurulacak akrabalık ilişkisi için hazırlanması gerekliliği hatırlatılır. Kız çocukları için ise hal ve hareketlerinde edep, ev işleri vb. uygulamalarda beceri kazandırma çabaları da yine bu düşüncenin ürünüdür. Zira bireylerin toplum içinde varlıklarını devam ettirmesi için, bir toplum; toplumun kendisini var edebilmesi için ise 
kültüre ihtiyacı vardır. Toplumların varlıklarını devam ettirebilmesi, sahip oldukları kültürel belleğin aktarımı ile mümkündür. Kültürel belleğin kuşaklar arasında aktarımında ise en etkin araç aile kurmaktır.

Aile insanın kültürel bir varlık olduğu zamandan günümüze kadar "tabiat güdüsüyle belli bir amaca, yani kadın ve erkeğin cinsi duygularla birleşmesinden ibaret karşılıklı menfaatlere yönelik bir kuruluş olmayıp" toplumun en temel çekirdeği ve gelecek nesillerin yetiştirilerek toplumun devamının sağlandığı temel bir kültürel kurumu oluşturmaktadır (Çalışkan ve Oral, 2016:227). Kültürümüzde aile olmanın gerekliliği, akrabaların ve eşindostunda katılımı ile gerçekleşen ve ilanı ile meşrulaşan birlikteliğin kutlandığı evlilik törenleridir. "Evlilik iki insanın; din, kültür, coğrafya, ekonomik durumu, eğitim düzeyi gibi şartlara bağlı olarak değişen, çeşitli inanış ve uygulamalar çerçevesinde bir araya gelerek yuva kurmalarıdır". Insan yaşamı üç temel geçiş dönemine sahiptir. Bu evreler; doğum, evlenme ve ölüm olarak sıralanmaktadır. Bu geçiş dönemlerinin ikincisini oluşturan evlenme, bireylerin aile kurarak nesillerini devam ettirmeleri yanı sıra, sosyal hayatlarında ki düzen ve istikrarındaki rolü nedeniyle evrensel bir nitelik taşımaktadır (Kılıç ve Altuncu, 2014:1). Buna ek olarak evlenme şekilleri ve gelenekleri kültürel unsurların bir sonraki kuşağa aktarımında taşıyıcı işlev gördüğü gibi bu unsurların yaşatılmasında da önemli bir rol oynamaktadır. Evlenme biçimleri ve süreçleri, sosyal çerçeve içerisinde inançlardan giyimkuşama, aileye verilen değerden yardımlaşma kurumuna kadar pek çok kültürel unsuru barındırmaktadır (Erol, 2016:228'den akt: Kabak, 2017:55). Düğün törenleri süresince gerçekleştirilen her ritüel bireylerin ait olduğu toplumsal kültürel belleğin ürünleridir ve bu ürünler somut olmayan kültürel mirasın alanlarını (sözlü kültür unsurları, yeme-içme ve bitki kültürü, gösteri sanatları, toplumsal uygulamalar ve el sanatları) oluşturmaktadır. Bu açıdan bakıldığında düğün töreni ile ilan edilen evlilik, her toplumda gerçekleştiği toplumun ait kültürün belirlediği yazılı olmayan kural ve kalıplar çerçevesinde (töre, adet, gelenek ve görenek) gerçekleşmesinden dolayı büyük bir zenginliğe sahiptir. 
Çalışmamızın alanını oluşturan ve tarihi geçmişi kadar somut ve somut olmayan kültürel miras unsurları bakımından da zengin olan Isparta ilinde de evliliğe giden süreç boyunca gelenekler çerçevesinde gerçekleşen uygulamalar sadece ilçe ve köylerde değil hatta mahalleler bazında dahi değişiklik göstermesi bakımından büyük bir zenginliğe sahiptir. Bu bağlamda Isparta'ya ait evlenme adetleri genel bir çerçevede ele alınması mümkün olmadığından, “kız isteme, söz-nişan, kına ve düğün“ başlıkları altında yöresel farklılıkları ile tanıtılmaya çalışılmıştır.

\section{Kız İsteme}

Evlenme adetleri içerisinde yer alan geleneklerin ilki kız istemedir. Kız istemedeki asıl amaç büyüklerin bu evliliğe ikna olması ve yeni yuva kurmaya adım atan gençlerin başlarının bağlı olduğunun herkese duyurulmasıdır, zira artık evlilik yoluna girmiş olan bu gençler için görücülük yapma işi bitmiş, dünürcü olarak gelmek isteyenlere yol kapanmıştır. Ülkemizin birçok bölgesinde olduğu gibi Isparta ilinde de görücü usulü evlilik bugün hala az da olsa devam etmektedir. Görücü usulü evliliklerde kız evine oğlan evinden çekirdek aile dışındaki akrabalardan ya da sözüne güvenilir insanlardan bir ya da birkaçı ziyaret için gider. Burada gelin olacak kızın ikramı, tertibi, düzeni, giyim kuşamı, adabı ve edebi öncelikle bu görücü kişiler tarafından incelenir. Şayet istenilecek kız görücüler tarafından beğenilirse oğlan evi kız isteme için ziyareti gerçekleştirecektir. Görücü gidilen kız beğenilmişse bir süre sonra oğlan evinden kız evine niyeti belli eden bir ziyaretin gerçekleşeceği haberi gider. Oğlan evi aile büyükleri ile gerçekleştirdiği bu ziyarette kız evine ağız tatlılığı olsun anlamına gelen lokum götürür. Bugün daha çok çiçek ve çikolata ile bu ziyaret gerçekleştirilmektedir.

Isparta'da kız isteme oğlan evinin kız evine üç kez gitmesi ile tamamlanır. Ancak kızın veya ailenin bu evliliğe rızası yok ise "kızımız küçük" gibi sözlü bahanelerle ya da Çetince Akçaşar Köyü'nde olduğu gibi oğlan tarafının ayakkabılarının çıkarıldığı yerde olmaması veya düzensiz kalması 
gibi davranışlar ile ilk ziyarette niyet belli edilir. Şarkikaraağaç İlçesi Gedikli Köyü'nde ve Aksu illçesinde ayakkabıların ters çevrilmesi ise kızın evliliğe razı olduğu ve sonucun olumlu olduğu anlamına gelmektedir. "Allah'ın emri, peygamberin kavli ile..." istenen kız verilmiş ise söz kesimi yapılır.

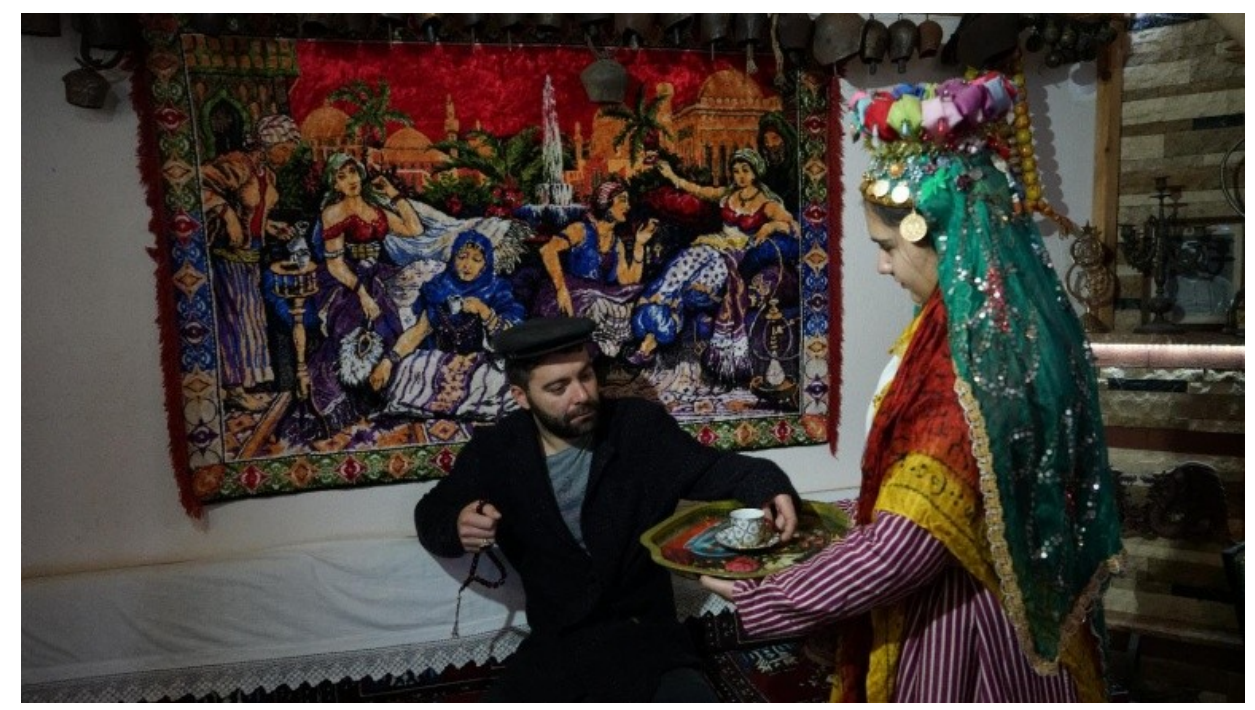

Görsel 1. Isparta ili kız isteme adetleri, 2019, SDÜ SOKÜM projesi arşivi.

\section{Söz Kesme ve Nişan}

Söz Kesme, gelin ve damat adaylarının evlilik yolunda verecekleri sözün aileler arasında resmileştirildiği aşamadır. Yöre ağzında ki çeşitlilik nedeni ile söz kesme törenine "el öptürme" “kız bitirme" veya "gelin bitirme" denilmektedir. Kız evinden olumlu yanıt alan oğlan evi aile büyükleri ile yakınları söz kesmeye kız evine giderler. Dua ile sözleri kesilen gelin ve damat, ev halkının ellerini öper ve bu esnada kayınvalide gelinin omzuna attığı oyalı yazma ile kızın sözünün takıldığını hane halkına duyurur. Oğlan evi kız evine giderken bisküvi, lokum ve çerez gibi hediyeler götürmesi bir gelenektir. El öpme merasiminden sonra oğlan evinden gelen hediye yiyecekler misafirlere ikram edilir. Şarkikaraağaç ilç̧esi'nde söz kesimi "şerbet içme ve küpe takma" olarak bilinir. Aileler tarafından daha önce 
belirlenen tarihte akşam ile yatsı namazı arasındaki vakitte dualar okunarak söz kesimi yapılmaktadır. Yakın döneme kadar dualardan sonra geline kayınvalide tarafından takılan küpe söz yüzüğü yerine geçmekteyken, günümüzde yine aynı işleyişten sonra gelin ve damada yüzük takılmaktadır (Dolunay, 2016:129).

II genelinde söz ve düğün arasında genellikle altı ay süresi olur. Bu süre hem oğlan evi hem kız evi için hazırlıklarını tamamlayabilmeleri için gerekli olan zamandır. Şayet bu süre altı aya geçecekse nişan merasimi yapılır. Özbayat köyünde Kız evinde gelinin ellerine ve saçına kına yakma törenine "nişan" denir. Çetince Köyünde ise nişan törenine "şerbet içme" denir. Nişan gününden bir gün önce davetlilere yemek verilir ve yemeğin ardından konuklara şerbet ikram edilir. Her odaya davetlilerin nişanlı çifte yeni kuracakları yuvaya katkı olması için bırakacağı para ve hediyeler için bohça açılır ve hediyeler bu bohçalar konur. Oğlan evi gelinin başına kına yakmak için, kız evinden bir gün belirlemesini ister. Belirlenen günde oğlan evi kız evine kına yakmak için misafir olur. Gelinin kınasını yakın zamanda evlenmiş başka bir gelin yakar. Her iki aileden sadece kadınların katıldığı kına yakma eğlencesi tef eşliğinde yapılır. Kına yakma işinin bitimiyle artık kız nişanlanmış olur. Yörede nişanlı sözü yerine "adaklı" ya da "başı kınalı" denmektedir. Nişanı yapılan gençler için artık düğün hazırlıkları hızlanmalıdır çünkü yörede nişandan sonra düğün için uzun süre beklenmez. Kız çeyizlerini tamamlarken erkek tarafı oku ya da okuntu denen davetiyeleri hazırlamaya başlar ve bunları düğünden bir hafta önce dağıtır. Oku olarak sabun, çorap, havlu, başörtüsü, basma kumaş gibi hediyeler hazırlanır.

\section{Kına Gecesi}

Türk inançlarında kına yakmak, yakılan kişinin seçilmiş/adanmış ve mukaddes olduğunu yani koruma altına alınmış olduğunu gösterir. Bu bağlamda onlara dokunmak, onlara saygısızlık göstermek, uğursuzluk ve felaket getirir inancı yaygındır. Bunun içindir ki "Vatana kurban olsun" diye asker adayına, "Allah`a kurban olsun" diye kurbanlık koçlara, "Eşine kurban olsun" diye geline kına yakılmaktadır. Gelinin ve damadın kına yakılarak ata 
evinden çıkarılması hem evlenen çiftin hem de yeni kuracakları yuvanın kutsanması anlamını taşımaktadır (Kalafat, 1990:91'den ve Santur, 2005:189'dan akt. Tokmak, 2009:21). Isparta'da "gelin okşama” ve "damat okşama" olarak anılan kına gecelerinde kız evi ve oğlan evi bir araya gelmez. Her iki ailede kendi evlerinde evlatları için eğlence düzenler. Kına gecesikız evinde düzenlenmişse "gelin okşama", erkek evinde düzenlenmişse “damat okşama” denmektedir. Sadece kadınların katılabildiği gelin okşamada kadınlar kendi aralarında tef eşliğinde oyunlar oynar. Geline kına yakılırken bahtı benzesin, telli duvaklı gelin olsun diye gelinin yanına gelinlik çağına gelmiş bekar kızlar oturtulur.

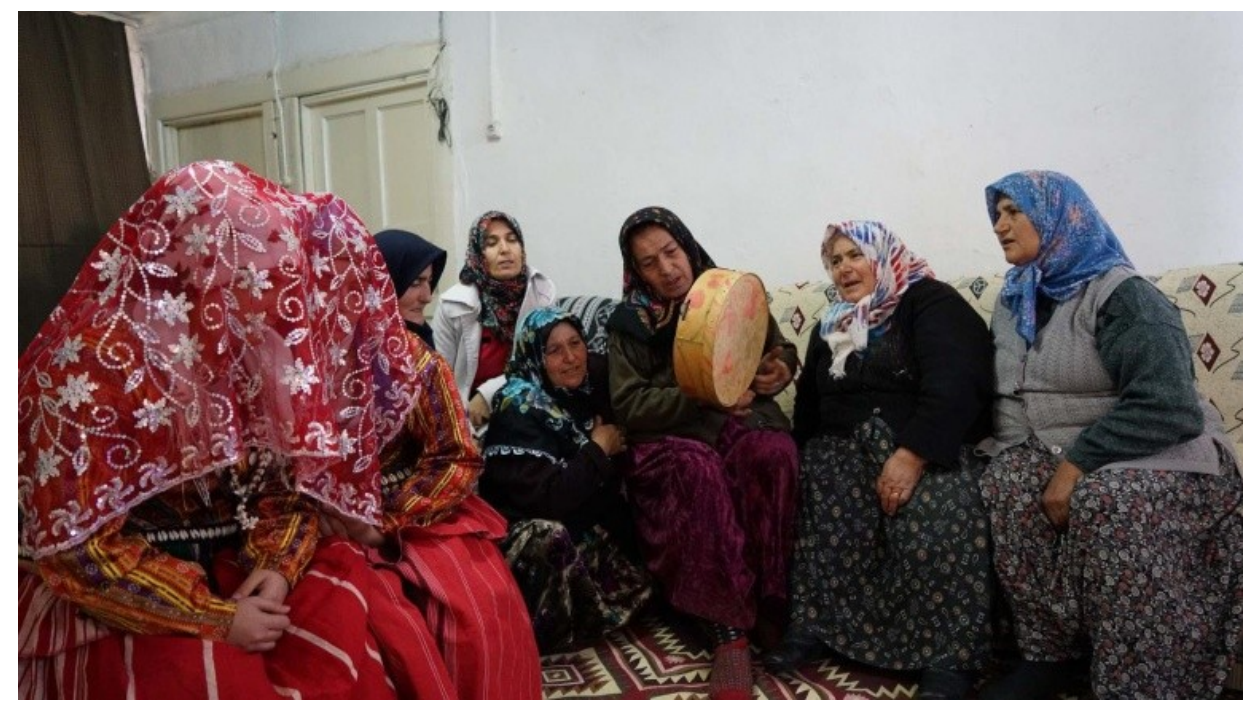

Görsel 2. Isparta ili gelin okşama, 2019, SDÜ SOKÜM projesi arşivi.

Anadolu'da olduğu gibi Isparta'da da gelinin gözyaşlarının bereket getireceğine inanılmaktadır. Bu nedenle gelin kına yakılmadan önce başına kırmızı örtü ötülür ve hasret, ayrılık, aile sevgisi konulu hüzünlü mani ve tef eşliğinde “kına okşama” türküleri söylenerek ağlatılır (Koşay, 1944:156-157). Kına okşamalarında gelinin avuç içine altın koymak sonradan adet haline gelmiştir. Yörede kına yakılmadan önce ve kına yakılırken söylenen gelin okşama türkülerinden biri şu şekildedir;

Bismillah deyin kınasına ünleyin gelsin halasına, Altın basın Kınasına Ay gızım kınan kutlu olsun. Yarenin dili tatlı olsun. 
Ak güvercin kayar gelir. Ak güvercin kayar gelir. Yavruları sayar gelir. Ay giz baban duyar gelir ay gızım kına kutlu olsun. Yarenin dili tatlı olsun hem orada hem burada dilin tatlı olsun. Kavak kavağa da yaslanır. Kavakta bülbül beslenir. Ay gız baban seni seslenir ay giz kınan kutlu olsun. Yârin ile dilin tatlı olsun. (Yalvaç Illçesi, 2019, Mehmet Çam ile yapılan görüşmeden) (Genç vd. 2019:25-26).

Kına yakılırken gelinin avucunda kayınvalide tarafından altın konması geçmişte yapılmayan, günümüz adetlerindendir. Kız evinde kadınlar tef eşliğinde eğlenirken, erkek tarafında ise "maşala eğlencesi" düzenlenir. Sadece erkek evinin erkek davetlilerinin katılabildiği maşala eğlencesi için köy meydanında ya da evin önünde büyük bir ateş yakılır ve bu ateş etrafında "deve oyunu", "arap oyunu" "tıraş oyunu", "kız kaçırma oyunu" gibi davetlilerinde oyuna katıldığı, güldürü amaçlı ve doğaçlama oynanan köy seyirlik oyunları oynanarak, damat tarafı eğlenir. Düğünlerde eğlendirme amacı ile oynan bu oyunlardan "kız kaçırma oyunu" şu şekilde oynanır;

Oyunda erkeklerden biri kadın kılığına girer. iki üç kişinin üstüne de kilim örtülerek deve yapılır. Davetlilerden bir kişi Arap olur, genç erkeklerden biri eline tüfek alır. Tüm karakterler aynı anda dügün alanına çıkar. "Selamünaleyküm" der davetlilerle selamlaşırlar. $O$ an için akla gelen bir şehir ismi seçilerek; "Biz Adana'dan geliyoruz, bir muhabbet var biz onun için uğradık kabul ederseniz muhabbetinize biz de ortak olacağız" derler ve kabul edilirler. Bu sırada köylü kendi arasında bir muhtar yaratır ve muhtar meydana çıkar yoldan gelen Arap ve oyun arkadaşlarını düğüne kabul eder ve oynamaya başlarlar. Bu sırada elinde tüfek olan delikanlı "bizim kız kaçırıldı" der. Köylülerden birkaç kişi jandarma olarak sahneye gelir ve kaçırılan kızı bulmaya çalışırlar. Davetlilerin arasına karışıp "Kim kaçırdı ?" diye sorulur. Kim kaçırdıysa mahkeme kurulur. Suçlular hapse gönderilir. Oyun biter.

Yörede genellikle düğünlerde yetişkinler tarafından maşala eğlencesi içerisinde güldürme amacı ile oynanan, seyirci-oyuncu ayrımını ortadan kaldıran, belli bir yapı içerinde sözlerin ve rollerin doğaçlama olarak 
sergilendiği, kimi zaman sonu ödülle biten bu köy seyirlik oyunları günümüzde neredeyse artık hiç oynanmamaktadır.

\section{Gelin Çıkımı ve Düğün}

Gelin çıkımı düğün günü gelinin babasının evinden alınarak damat evine getirildiği gündür. Geçmişte gelinin binmesi için süslenmiş bir at ile erkek evinden bir konvoyla baba evinden alınan gelin bugün damadın ve akrabalarının süslenen bir araba ile konvoy halinde gelini almaya gitmesine dönüşmüştür. Ancak araçlar değişmiş olsa da baba evinden duayla çıkarılan gelinin, yeni evine geldiğinde bereket ve huzur için yaptığı bazı ritüeller hala devam etmektedir. Bunlardan biri gelinin yeni evine geldiğinde üzerine şeker, para ve buğday saçılmasıdır. Buna ek olarak sağ ayakla girdiği eşiğin altına ve üstüne yağ sürmesi de; gelinin ve eşinin birbirlerine olan bağlıklarını ve muhabbetlerini arttıracağına inanılmaktadır.

Isparta'da geçmişten bugüne devam eden bir gelenekte düğünlerin "yer düğünü" denilen köy ya da mahalle meydanlarında yapılmasıdır. ì ve ilçe merkezlerinde daha çok salon tutarak yapılan düğünlere nazaran yer düğünleri azalmış olsa da adetlere uygun olarak evlenmek isteyen çiftler ve aileleri tarafından hala devam ettirilen bir evlenme şeklidir. Buna ek olarak ilde düğünlerin gün sayısı ve bu günlerde evliliğe dair yapılan işler farklılık göstermektedir. Gelinin baba ocağından çıkıp yeni evine gidinceye kadar süren düğün kutlamalarında her gün başka bir isim ile anılır. Bir örnek olarak birçok ilçe ve köyde düğün süresi genellikle yedi gün sürerken, Yalvaç İlçesi Körküler Köyü'nde düğün harç günü, kına günü, un-odun, yük-döşek, gelin çıkımı ve gelin ertesi olmak üzere altı gün sürer. Bu günlerden un-odun günü kaynatanın günüdür; çeyiz günü gelinin; gelin çıkımı damadın; gelin ertesi günü ise kaynananın günüdür. Düğün süresince ahali gökyüzüne bakar, hava açık ve güneşli ise evlilik iyi gidecek, hava bozuk, yağmurlu, karlı ya da çok soğuk ise, gün kiminse o kişinin bu evlilikte huzur bozacağına inanılır. Örneğin çeyiz günü hava kötü ise gelinin hayırsız olacağına, un-odun günü ya da gelin ertesi günü hava kötü ise kaynatanın ya da kaynananın bu evlilikte 
huzur vermeyeceği ve gelini üzeceğine, gelin çıkımı hava bozuk ise damadın geline kötü davranıp hoş tutmayacağına inanılmaktadır.

Geleneksel Isparta düğünlerinde en çok dikkat çeken unsurlardan biri de gelin giyimi ve ilçelerde farklı şekillerde hazırlanan gelin başlıklarıdır. Isparta'da gelinler, şalvar, içlik, üç etek, delme (yelek), kuşak, öncük, bel boncuğu ve ayağa giyilen yün çorap, şal olmak üzere on parçadan oluşmuş kumaş adı verilen kıyafeti giyerler. Bu kıyafet yörede düğün süresince yeni gelin olmuş her kadının giydiği bir kıyafettir. Genel olarak çok renkli olan bu kıyafetler düğün sonrası da gelin tarafından gelin ardı ya da ertesi denilen misafir ağırlama süresince de giyilmektedir.

Körküler Köyü'nde gelin kumaş denilen gelin kıyafetine ek olarak, keçe başlık, ziliflik, ikilik, çığa, gırpıntı, uştu, poçu ve pullu olmak üzere sekiz bölümden oluşan özel bir başlık takar. Gelin kıyafetlerinin en belirgin ve tipik özelliği başlıklardır. Gelinliğin en önemli parçalarından biri de siyah ya da lacivert kadife kumaştan, göz boncuğu, deniz boncuğu, düğme ve çeşitli kum boncuklarla işlenmiş "bel/soy boncuğudur". Kemer üzerindeki süslemeler çiçek şeklinde düzenlenir ve bu çiçek formuna ocak denmektedir. Küçük cevizler ve badem, ıslatılıp nemlendirildikten sonra delinerek süslemede kullanılır. Bel boncuğunun üzerindeki her bir yuvarlak desene "ocak" denir. "Ocak" sayısı kemerin uzunluğuna bağlı olarak değişse de mutlaka 7-9 gibi tek sayılı olur (Kartal, 2014:253'den akt. Çeliker, 2018:151). 


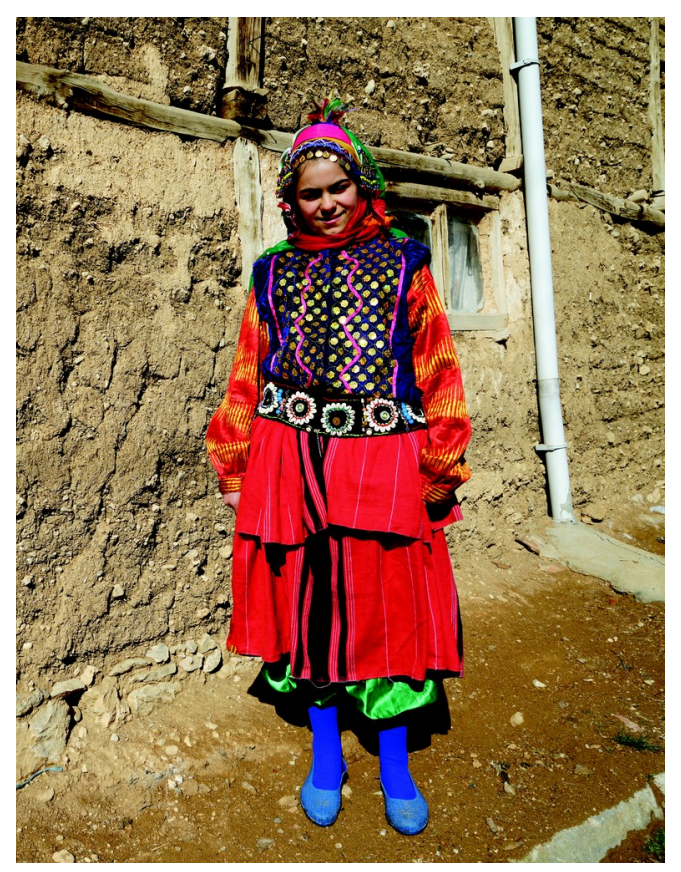

Görsel 3. Körküler Köyü gelin giyimi, 2019, SDÜ SOKÜM projesi arşivi.

Yalvaç İlçesi Körküler Köyü ve Celeptaş Köyü gelin giyimi başlıkları benzerdir. Ancak Körküler Köyü'nde renkli tüller fes üzerine üst üste örtülürken, Celeptaş Köyü'nde fesin arkasında kuyruk olarak demet halinde tutturulur. Bu örtülerin her biri rengine göre farklı temennileri temsil etmektedir. Beyaz örtü, saflığı; sarı örtü güneş gibi parlayıp huzurlu olmayı; turuncu örtü toprakla özdeşleştirilerek bereketi ve doğurganlığı; mor örtü sabır ve fedakarlığı; mavi renk huzuru; kırmızı renk sevgi ve muhabbeti temsil etmektedir. Gelinin başına takılan boyalı tüyler de yine aynı temennilerle hazırlanır. Bunlara ek olarak gelin başının önüne takılan ayna, boncuk ve renkli tüylerin gelini nazar ve kem gözlerden koruyacağına inanılmaktadır. Geçmişten günümüze varlığını sürdüren nazar inanışı, ülkemizin hemen hemen her köşesinde olduğu gibi Isparta'da da günlük hayatın içerisinde varığını devam ettirmektedir. Bugün halk arasında, nazara karşı mavi boncuk, delikli taş, nal, yumurta kabuğu, ayna gibi çeşitli nazarlıklar kullanma, muska yazdırma, kurşun dökme vb. çeşitli pratikler yapılmaktadır (Çıblak, 2004:104). Yöre gelin giyiminde başlıklarda ya da bele 
takılan kuşak süslemelerinde kullanılan mavi boncuk, deniz kabukları veya ayna gibi objelerde, yine bu korunma ve koruma isteği ile ortaya çıkmıştır.

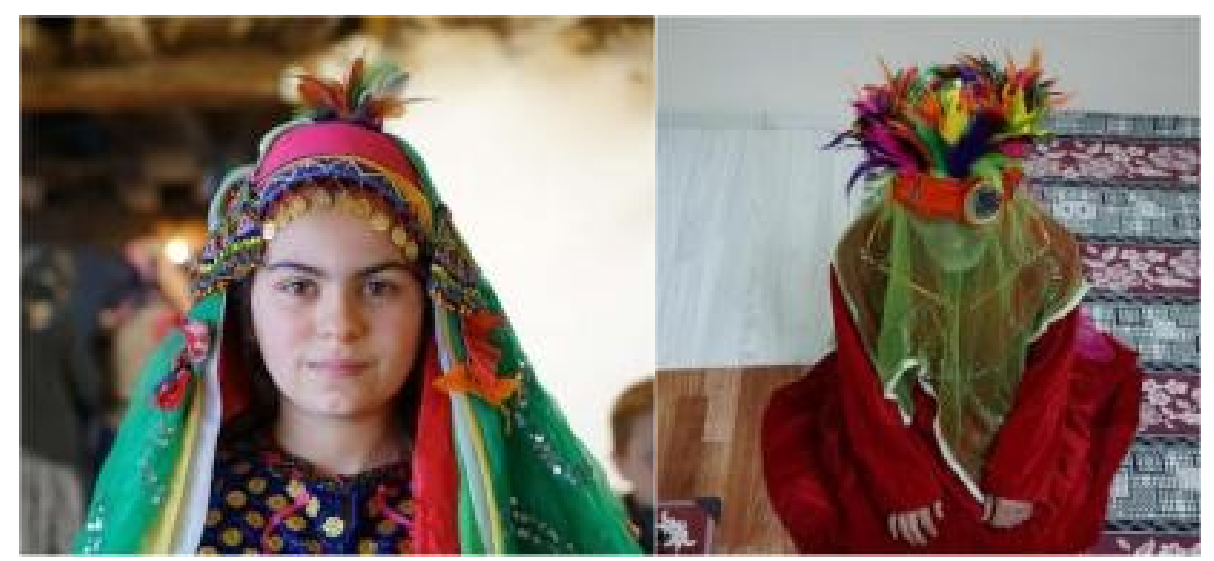

Görsel 4. Körküler Köyü Gelin Başı ve Celeptaş Köyü Gelin Başı, 2019, SDÜ SOKÜM projesi arşivi.

Senirkent İlçesinde ve Uluborlu İlçesi'nde gelin giyimi benzerdir. Her iki ilçede de gelin başlıkları aynı şekilde hazırlanır ve düğünün ertesi günü gelin yüzü şenliği gününde gelin başına bu başlığı takar. Bu şenliğe tüm eski gelinlerinde başlığı takarak katılması bir gelenektir. Başlığın üzerindeki organze kumaştan yapılmış tomurcuklar afyon bitkisinin tomurcuk formundan ve renklerinden esinlenilerek hazırlanmaktadır. Başlığın ön kısmında ki kaş denilen taşların ise nazara karşı koruyucu olduğu düşünülmektedir. Gelinin başına, yeni yuvasında huzur, bereket, sağlık ve mutlulukla bir filiz gibi yeşermesi dileği ile yeşil renk tül örtülmektedir.

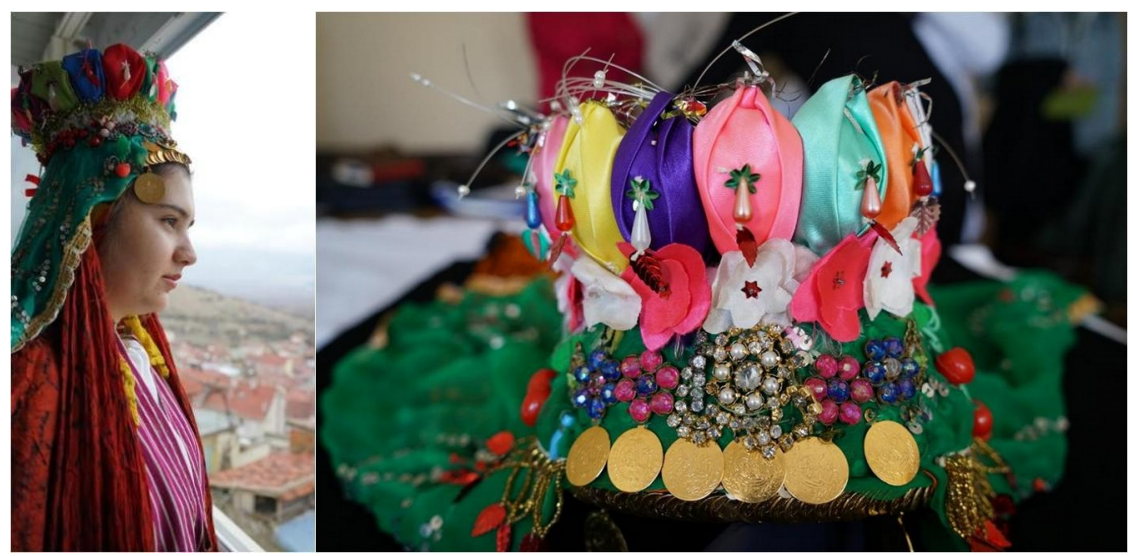


Görsel 5. Senirkent İlçesi Gelin Başı ve Uluborlu illçesi Gelin Başı, 2019, SDÜ SOKÜM projesi arşivi.

Sütçüler İlçesi gelin giyimi diğer ilçe gelin giyiminden farklıdır. Burada gelin giyimine urba denmektedir. Hentarinin üzerine kebe denilen sırtı sırma işlemeli ceket giyilmektedir. Bu ceketin bir benzeri Yalvaç ilıçesi Kozluçay yöresel giysilerinde "telli fermana" olarak bilinmektedir (Kartal ve Ölmez, 2014:103). Bu gelin giyiminin başlığı ise Yalvaç İlçesi Kuyucak Köyü gelin başlığı ile benzerdir. Diğer ilçelerdeki başlıklara nazaran daha sadece olarak takılan bu başlığın en önemli özelliği alına gelecek şekilde düzenlenmiş altın çekilerdir. Bu çekili başlık Aşağıyaylabel Köyü'nde günlük kullanımda da başörtüsü altına takılmaya devam edilmektedir. Başlıklarda ki altın çekiler kadın evli ise çift sıra, bekâr ise tek sıra olarak takılmaktadır. Böylelikle başlığı takan bir genç kız ise medeni durumu bilinmektedir.
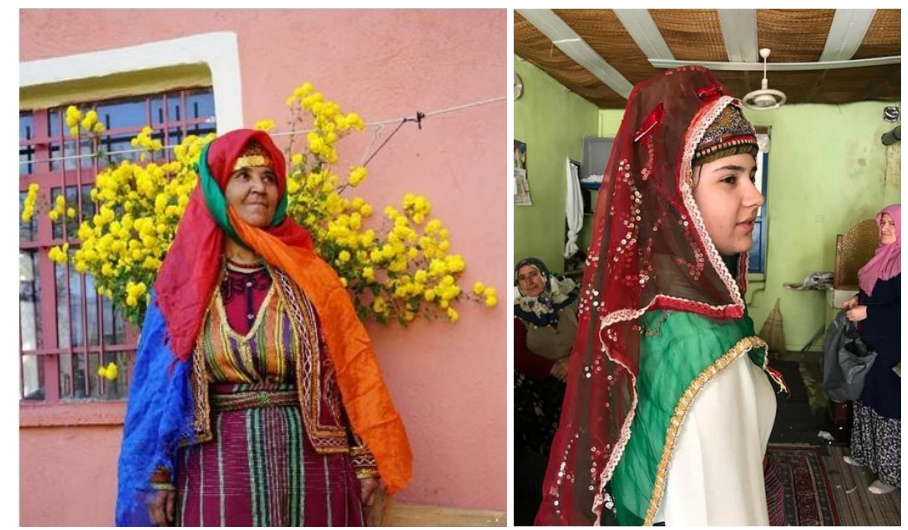

Görsel 6. Sütçüler İlçesi Kesme Köyü Gelin Başı ve Yalvaç İlçesi Kuyucak Köyü Gelin Başı, 2019 , SDÜ SOKÜM projesi arşivi. 


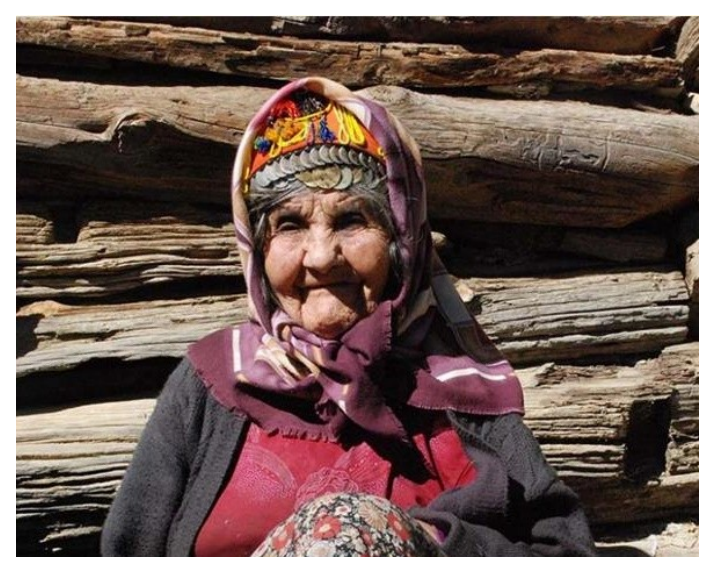

Görsel 7. Sütçüler İlçesi, Aşağıyaylabel Köyü günlük kullanımda Başlık, 2019, SDÜ SOKÜM projesi arşivi.

\section{Sonuç}

Kültürel belleğin kuşaklar arasında aktarımında en etkin araçlardan birisi, hem sözel hem de eylemsel olanı kapsayan(somut olmayan kültürel miras alanlarından toplumsal uygulamalar içerisinde yer alan) evlenme adetleridir. Evlenme, bireye yeni bir konum ve kurulan akrabalık ilişkileri ile varlık kazandırır. Kültürümüzde evlilik eş-dost ve akrabaların katılımı ile gerçekleşen kutlu bir törendir. Evlik süresince gerçekleştirilen her uygulama, kutlandığı toplumun inanç, inanma, gelenek, sosyal ve ekonomik yapısına göre çeşitlilik göstermektedir. Buna ek olarak ülkemizde 1930'lu yıllarda salonlarda düğün yapma geleneğinin yaygınlaşması ile geleneksel düğün biçimleri hızlı bir değişime uğramıştır. Geçmişte yedi günü bulan emek isteyen düğünler, yerini iki günü kapsayan (kına ve balo) salon düğünlerine bırakmaya başlamıştır. Bir toplumda kültürel bellek unsurlarından birinin yok olması, o alanda ki anlamın da kaybolması demektir. Kültürlerde her yapı bir diğer yapı ile bağlantılıdır. Örnek olarak gelin başına yeni kurulan aileyi kutsamak ve kem gözden korumak için dua ve manilerle takılan süslemeler (renkli tül, tüy, boncuk, ayna vb.) yerine, batıdan esinlenilerek takılan beyaz duvağın tercih edilmesi, sadece geleneksel gelin giyiminin kültürden çıkarılması değil onunla birlikte sözlü kültür unsurlarının ve (nazar, bereket vb.) toplumsal uygulamalarının da o kültürden çıkarılması anlamına gelebilir. $\mathrm{Bu}$ durum toplumun kimliğinin melezleşmesine hatta zaman içerisinde 
kimliğini kaybetmesine neden olabilir. Ancak kültürel değerlerine bağlı toplumlarda geçmiş nitelikleri ile bire bir örtüşmese de hala geleneksel evlenme uygulamaları ile karşılaşmak mümkündür. Bu bölgelerden biride Isparta ilidir. Isparta il merkezinde daha çok salon düğünleri yapılıyor olsa da ilçe ve köylerinde yer düğünü denilen geleneksel düğünler az da olsa devam etmektedir. Nitekim düğünlerde toplu yemek yeme adeti, düğün yemeğinde yöreye özgü kabune pilavı ikramı, davetiye yerine oku dağıtma geleneği, gelin okşama adeti ve ritüelleri, kına günü gelin ve arkadaşlarının geleneksel gelin kıyafetini giymesi, vb. uygulamalar geçmiş ve bugün arasında biçimsel farklılıklar olsa da hala yörede devam eden geleneklerdir.

\section{Kaynakça}

Çeliker, D. (2018). "Körküler'de (Isparta) Düğün ve Yöresel Tekstiller",Düğün Kitabı, ed. Emine Gürsoy Naskali ve Aysel Güneş, Ankara: Libra Yayıncılık.

Dolunay, S. ve Dolunay, S. (2016). Kızıldağ'ın Gölgesinde Tarihçesi ve Folkloruyla Şarkikaraağaç, Ankara: Pegem Akademi Yayın Eğitim Danışmanlık.

Genç, M. ve Çeliker, D. ve Kodal, T. vd. (2019). “Isparta'nın Somut Olmayan Kültürel Mirası", ed. Bilge Hürmüzlü Kortholt, Ankara: Desen Ofset.

Kabak, T. (1997). Trabzon-Arsin İlçesi Düğün Adetleri, Bartın: Bartın Üniversitesi Edebiyat Fakültesi Dergisi, ISSN:2547-9865,Cilt 2, Sayı 1.

Kalafat, Y. (1990). Doğu Anadolu'da Eski Türk Inançlarının Izleri, Ankara: Ebabil Yayınevi.

Kartal, Z. ve Ölmez, F. N. (2014). Isparta Yöresel Kadın Giysileri, Isparta: Isparta II Kültür ve Turizm Müdürlüğü.

Santur, M. C. (2005). “Kastamonu Evlenme Adetlerinin Halkbilimsel Açıdan İncelenmesi", ikinci Kastamonu Kültür Sempozyumu Bildirileri, Ankara.

Tokmak, Y. (2009). Balıkesir ve Çevresinde Kına Folkloru Üzerine Derlemeler ve incelemeler, Balıkesir: Balıkesir Üniversitesi, Sosyal Bilimler Enstitüsü, Türk Dili ve Edebiyatı Anabilim Dalı, Yayınlanmış Yüksek Lisans Tezi.

\section{Internet Kaynakları}


Çalışkan, Ş. S. E. ve Oral, Ş. (2016). "Safranbolu'da Evlilik Âdetleri”, Uluslararası Sosyal Araştırmalar Dergisi, Cilt 9, Sayı 43, http://www.sosyalarastirmalar.com/cilt9/sayi43 pdf/

1dil_edebiyat/erolcaliskan_seher.pdf, Erişim tarihi: 17.09.2019.

Çıblak, N. (2004). "Halk Kültüründe Nazar, Nazarlık İnancı ve Bunlara Bağlı Uygulamalar", Türklük Bilimi Araştırmaları, https://dergipark.org.tr/tr/download/article-file/156801, Erişim tarihi: 17.09.2019.

Kılıç, S. ve Altuncu, A. (2014). "Karakoçan'da Evlilik Adetleri", Ankara: International Periodical for The Languages, LiteratureandHistory of TurkishorTurkic, Vol. file:///C:/Users/ User/Downloads/KARAKOCAN_DA_EVLILIK_ADETLERI_MARRIAGE_C.pdf, Erişim -tarihi:17.09.2019.

\section{Görsel Kaynaklar}

Bu çalışmada kullanılan tüm görseller 2017 yılında Süleyman Demirel Üniversitesi Bilimsel Araştırma Projeleri Koordinasyon Birimi desteği ile başlatılan "Isparta Somut Olmayan Kültürel Mirasın Tespiti" isimli projenin arşivine aittir. 